\title{
Natural Isotopes and lon Compositions Identify Changes in Groundwater Flows Affecting Wetland Vegetation in the Drentsche Aa Brook Valley, The Netherlands
}

\author{
Samer Elshehawi ${ }^{1,2,}$, Enno Bregman ${ }^{3,4}$, Paul Schot ${ }^{5}$, Ab Grootjans ${ }^{1,6}$ \\ 1 Centre for Energy and Environmental Studies, University of Groningen, The Netherlands. \\ 2 Centre for Isotope Research, University of Groningen, The Netherlands. \\ 3 Province of Drenthe, The Netherlands. \\ 4 Physical Geography Department, University of Utrecht, The Netherlands. \\ 5 Copernicus Institute of Sustainable Development, University of Utrecht, The Netherlands. \\ 6 Institute of Water and Wetland Research, Radboud University Nijmegen, The Netherlands. \\ * Corresponding author's e-mail: s.e.a.a.elshehawi@rug.nl
}

\begin{abstract}
This study uses groundwater isotopes and ion composition to verify model simulations and ecohydrological studies in the Drentsche Aa nature reserve in The Netherlands, which is representative for the northwestern wetland areas in the Ice Marginal Landscape zone. At eight field sites, a total of 24 samples were analysed for their ${ }^{13} \mathrm{C}$, ${ }^{14} \mathrm{C},{ }^{2} \mathrm{H}$, and ${ }^{18} \mathrm{O}$ isotopes and ionic composition. The isotopes indicate that most of the fen peatlands in the area depend on the exfiltration of sub-regional groundwater flows, which confirmed the previous model simulations and ecohydrological studies. At three sites, isotopes and ionic composition indicate that the groundwater from the sub-regional system has been replaced by local infiltrated rainwater, due to nearby groundwater abstractions for drinking water, which influenced the success rates of the restoration measures. Furthermore, the evidence from chloride and ${ }^{14} \mathrm{C}$ contents was found to indicate the presence of more saline groundwater, which are influenced by the groundwater flows near salt diapirs. Groundwater abstractions may enhance the upward flow of the saline groundwater to eventually exfiltrate at the wetlands, affecting the biodiversity of the nature reserve.
\end{abstract}

Keywords: ecohydrology, groundwater modelling, nature conservation, radiocarbon dating, groundwater abstraction.

\section{INTRODUCTION}

The wetland vegetation is strongly infleunced by hydrology [Wheeler \& Shaw, 1995; Gilvear \& Bradley, 2009], notably by the interactions between local, sub-regional and regional groundwater flow systems [Tóth, 1963; Schot \& Molenaar, 1992; Dahl et al., 2007; Van Loon et al., 2009]. Such interactions among the groundwater flows lead to different types of groundwater-dependent ecosystems [Wassen et al., 1990]. An example of such systems is the Drentsche Aa Brook Valley, which is a nature reserve in the north of the Netherlands. This valley is characterized by various types of wetlands, agricultural fields, heathlands and small villages. The heathlands, forests and wetlands are all part of a protected nature reserve [Van Diggelen et al., 1995]. Different types of wetland vegetation are dependent on various water sources, with the biodiversity-rich fen peatlands primarily depending on the groundwater flows from phreatic and semi-confined groundwater aquifers [Grootjans et al., 1993; Van Diggelen et al., 1995]. Everts \& De Vries [1991] illustrated the hypothetical groundwater systems in Drentsche Aa based on the vegetation gradients using the theoretical framework from the groundwater systems by Toth, [1963] (Figure 1). These 
local and sub-regional groundwater systems have been intensively studied and the results have been used for nature and landscape policy plans.

However, the area is part of the Ice Marginal Landscape zone, and geological proccesses such as the pro- and postglacial differential Saalian and Weichselian rebound and the sub-glacial deeply eroded Elsterian channel systems are not well understood, especially in relation to the groundwater flows (Figure 2a) [Smit et al., 2015]. On the basis of better geological input, Magri \& Bregman [2011] simulated the groundwater flows in the area using particle tracking, where they indicated the areas of infiltration and exfiltration of groundwater on sub-regional and local scales. One of the model outcomes was that salt plumes might diffuse into the groundwater exfiltrating into the wetlands, due to the influence of double diffusive convection (DDC) processes [Diersch \& Kolditz, 1998], and compromise the wetland biodiversity under increased groundwater abstraction rates (Figure 2b). These salt plume formations originate from the intrusive salt diapirs of the Zechstein formation [De Vries, 2007; Magri \& Bregman, 2011].

Another threat to the nature reserve involves the groundwater abstractions for drinking water production from the semi-confined aquifers [Mendizabal \& Stuyfzand, 2009; Mendizabal et al., 2011] at two locations adjacent to the brook valley (Figure 2). These may change the natural groundwater flow patterns, which in turn may affect the wetland vegetation and biodiversity. Such impacts have been reported for European wetlands [e.g. Wassen et al., 1990; Schot \& Van der Wal, 1992; Grootjans et al., 1993].

Although the Drentsche Aa nature reserve has been widely studied, uncertainties remain, i.e. regarding the reliability of the simulated flow patterns and possible up-coning of salt plumes. The accuracy of the groundwater simulation models depends on the underpinning assumptions and the availability of adequate data. The ecohydrological studies using plant species occurrence as indicators for groundwater flow systems may disregard the time lag in the response of plant species following groundwater flow changes due to e.g. buffering of soil water quality due to the buffering processes in the soil.

Simulated groundwater flows may be validated by independent hydrological tracers, such as chloride and natural isotopes [Schot \& Molenaar, 1992; Gibson et al., 2005; Mayer et al., 2014]. The natural isotopes used as tracers in the ecohydrological research related to groundwater, have been mostly limited to the stable isotopes of oxygen and hydrogen [e.g. Schot \& Wassen, 1993; Isokangas et al., 2017]. Radioactive isotopes, especially radiocarbon, are less commonly used due to practical reasons, e.g. sample volumes and analysis costs [Mook, 2006]. In the study area, the radiocarbon age dating of groundwater may provide insight into the residence times which reflects the groundwater flow systems affecting the wetland vegetation. Young groundwater will generally reflect the local flow systems with recently infiltrated water from the vicinity and possibly showing the human pollution signs in their ionic composition. Old groundwater may, however, indicate the deep groundwater flow from subregional to regional systems, which would have recharged long ago showing enhanced mineral dissolution and free from human pollution. Additionally, deep groundwater affected by the DDC near the salt domes would show lower ${ }^{14} \mathrm{C}$ activity, and enriched $\delta^{18} \mathrm{O}$ values and/or high salinity

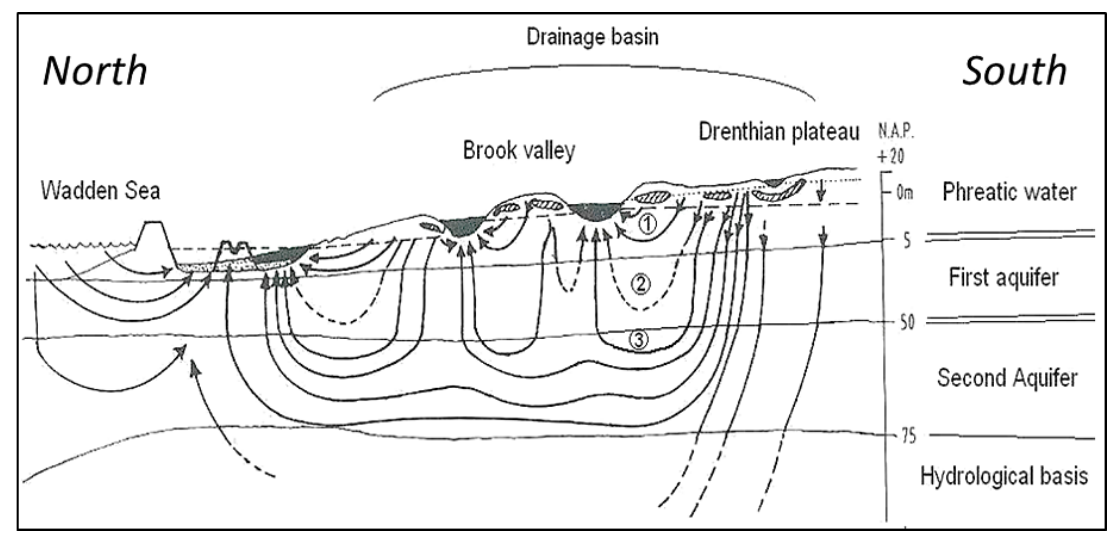

Figure 1. An illustration of the hypothetical groundwater flow systems conditioning the ecohydrological systems in Drentsche Aa Brook Valley [Source: Everts and De Vries, 1991] 
a)

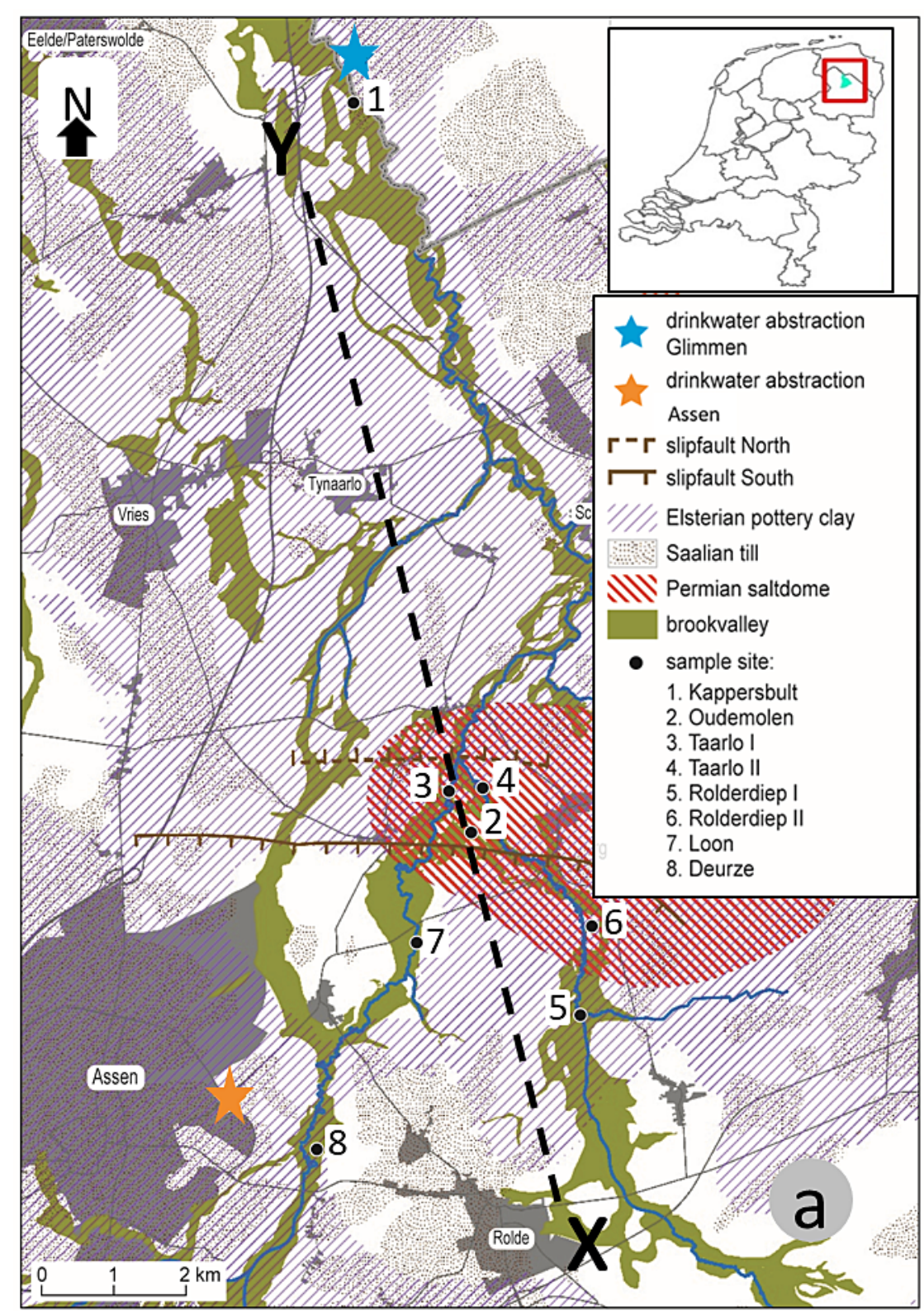

b)

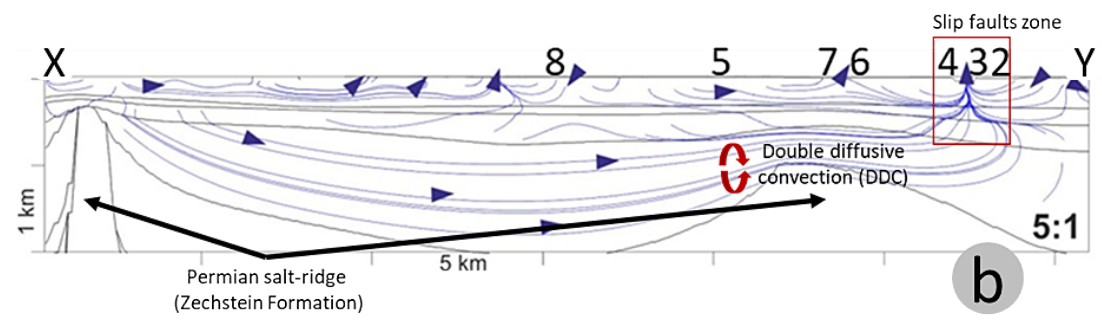

Figure 2. Groundwater sampling sites and geological features that control the flow patterns in the groundwater (a), simulation model results show the effect of the double diffusion convection along the X-Y transect in (a), which affects groundwater reaching the surface (b)

from the evaporites present in the salt diapirs. Stable isotopes may also indicate increased stable isotope values as a result of increased evaporation during slow infiltration through peat layers, as compared to present-day rain water, or signal different rain water isotope characteristics in ancient recharge water.

This study uses groundwater isotopes in the Drentsche Aa brook valley to validate (i) the origin of groundwater flows to the fen peatlands as 
indicated by the model simulations by Magri and Bregman [2011] and by ecohydrological studies [e.g. Everts \& De Vries, 1991; Grootjans et al., 1993 and Van Diggelen et al., 1995], (ii) the influence of groundwater abstractions on the groundwater flow, and (iii) the possible salination of shallow groundwater in the nature reserve by upconing water from salt diapir evaporites. Furthermore, the study aims to assess restoration success in light of these investigations.

\section{STUDY AREA}

The Drentsche Aa brook valley is the bestpreserved brook valley landscape in the Netherlands $\left(53^{\circ} 1^{\prime} 52.18^{\prime \prime}\right.$ N. 6 6 38'17.10'E, Figure 3). Almost all the streams still meander in a natural way and the heathlands, fen meadows, forests and cultural aspects of the landscape are still in good condition and were partly restored to a former state [Bakker et al., 1980]. The total catchment area of the Drentsche Aa is about 30,000 ha. Out of these, only 3,500 ha are managed to restore the semi-natural landscape of c. 1900. The topography of the landscape consists of a plateau at a height of about $28 \mathrm{~m}$ AMSL in the upper reaches, with the brook valley following the topographic relief to reach the height of about $0 \mathrm{~m}$ AMSL in the lower reaches at Kappersbult.

According to De Vries [2007], the rainfall averages in the Netherlands are relatively constant with a precipitation surplus of $250-300 \mathrm{~mm}$ a year that mostly falls during winters. The fresh groundwater flows in the eastern parts of the Netherlands, including the Drentsche Aa valley, are within the Plio-Pleistocene sandy aquifer. This aquifer is mostly unconfined, with the

a)

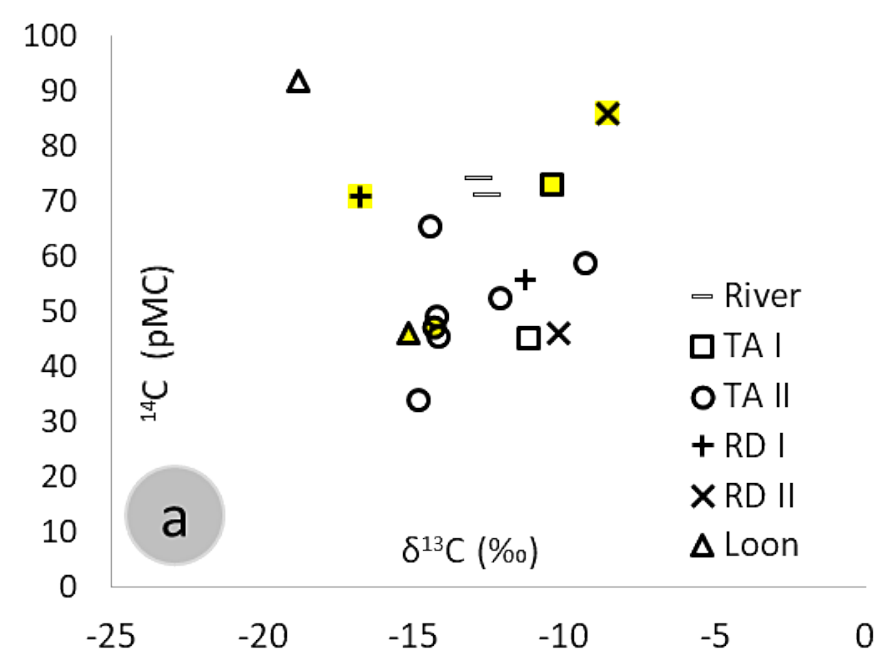

b)

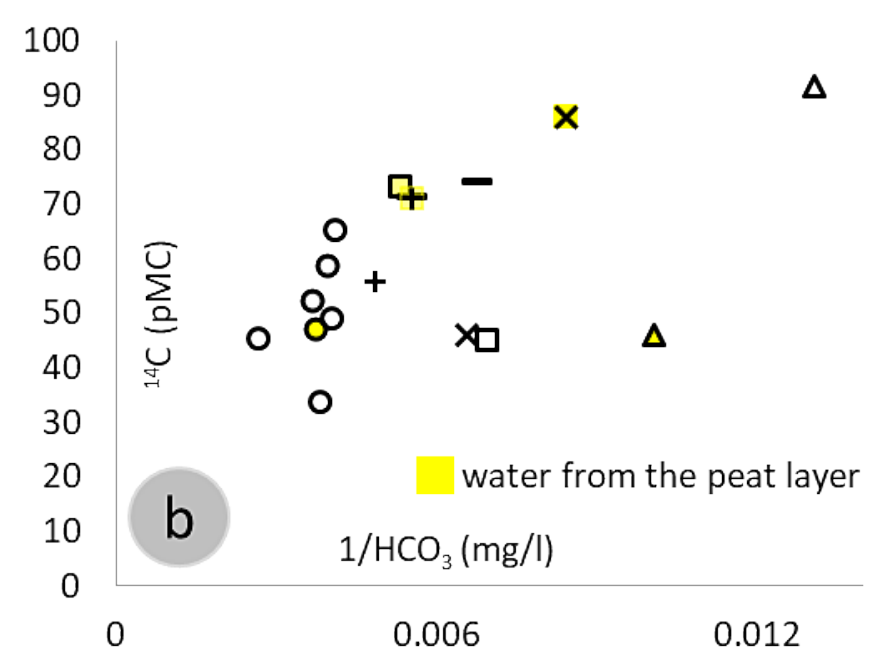

Figure 3. Relationships of the ${ }^{14} \mathrm{C}$ (pMC) content in the water samples with (a) $\delta^{13} \mathrm{C}(\%)$, and (b) the reciprocal of $\mathrm{HCO}_{3}(\mathrm{mg} / \mathrm{l})$ 
thickness ranging between 150-250 $\mathrm{m}$ in Drenthe [De Vries, 2007; Mendizabal et al., 2011]. The aquifer sediments are mainly medium-sized, with intercalation of finer sediments [De Vries, 2007]. The Breda formation is a clay layer of marine origin that exists at a depth of 150-250 m in Drenthe, which represents the hydrological basis of the fresh water systems [De Gans, 2007]. The subregional and regional groundwater flows are controlled by four elements: slip-fault systems that border a tilted tectonic block [Smit et al, 2018], the Zechstein salt diapir, the interspaced lacustroglacial Elsterian clay layers (Peelo 1 and Peelo 2 formations), and the Saalian tills (boulder clay) (Figure 2a). The slip-faults are difficult to trace due to (un)consolidation of the sediments [De Gans, 2007]; however, it has been improved by new interpretation techniques: such as extrapolation of deep faults in 3D and SKY-TEM data [Smit et al, 2018]. Bregman et al., [2015] indicated that the faults influence the morphology of the surface area, as well as the functioning of the regional hydrological systems which is based on top of the Zechstein Formation. This formation is strongly undulating with salt diapirs at some areas.

\section{METHODS}

\section{Selected sites}

We selected eight study sites based on four hydrogeologic drivers and/or controllers: traced fault structures, Zechstein salt diapir depth, the Saalian tills (boulder clay) and Peelo-I and II clay formation(s) (Figure 2). The fault structures were obtained from Bregman et al. [2015]. The thickness and locations of the Zechstein and Peelo formations in the study area were obtained via "Dinoloket", which is an online platform for 2D and 3D models of geological layers in the Netherlands [Dinoloket, 2014].

The following eight study sites were selected (Figure 2a):

\section{Lower reach}

The first one was Kappersbult in the lower reaches of the valley. It has a $6 \mathrm{~m}$-thick peat layer that indicates paleo groundwater exfiltration, although it was identified as an infiltration area when investigated by Van Diggelen et al. [1994]. Restoration measures were applied to allow flooding in the Kappersbult reserve, but the effects of drainage by agriculture and water abstraction could not be prevented [Bakker et al., 1980; Van Diggelen et al., 1994]. Furthermore, it was indicated as an infiltration area by groundwater flow simulation, due to the groundwater abstraction from the station in Glimmen (Figure 2) [Magri \& Bregman, 2011].

\section{Middle reach}

Six sites were investigated: Oudemolen, Taarlo-I and -II, Rolderdiep-I and -II and Loon. In this area, the fault structures are traced in the northern part of the area. On top of the raised tectonic block, which is slightly sloping to the north and borders with the two slip faults (Figure 2a) [Smit et al, 2018]. The Peelo-1 layer is present at Taarlo-II at a depth of about $10 \mathrm{~m}$ below the surface and Peelo-II layer at a depth of about $42 \mathrm{~m}$ below the surface. On top of the raised block, the peat layers have a thickness of 1.5 meter in the small river valley. The situation in this location is in strong contrast to Loon and Rolderdiep-I. These two sites are just above a lowered tectonic block and part of the rim syncline of the Anloo salt dome. At Loon, only the Peelo-2 layer is present at the depths of about $40-50 \mathrm{~m}$ below the surface. The peat thickness in this part of the study area with a broad valley reaches up to $6.5 \mathrm{~m}$. The differences in geology and morphology in this part of the study area and the downstream part on top of the (raised) tectonic block are also reflected in the hydrological situation with strong seepage. In spring, this part of the study area is impassable because of floating peat layers caused by stagnation of drainage. Loon, is described by Grootjans et al. [1993] as a valley with groundwater exfiltration from the sub-regional groundwater system. However, the groundwater simulations indicated the influence of groundwater abstraction from the nearby pumping stations, i.e. Assen (Figure 2), which could have changed the groundwater flow paths [Magri \& Bregman, 2011]. All of these sites, except for Oudemolen, receive higher rates of groundwater discharge, ranging from 1.4 to 4.2 $\mathrm{mm} /$ day [Grootjans et al., 1993]. Oudemolen, is a small bog situated in a heathland within an infiltration area [Grootjans et al., 1993]. It is characterized by very low productivity and only receives acidic rainwater poor in minerals [Van Diggelen et al., 1995]. The site has a podzolic B-horizon that prevents rapid infiltration of precipitation water. 


\section{Upper reach}

Deurze is located in the upper reaches of the Drentsche Aa valley. The depth of the Peelo-I layer is about $10 \mathrm{~m}$ from the surface, where it prevents deep groundwater exfiltration [Grootjans et al., 1993; Van Diggelen et al., 1995]. The seepage intensities of groundwater were estimated to be around 0.7-1.4 mm/day [Grootjans et al., 1993]. This area was indicated by the model to be limited to local groundwater flows, due to the shallow depth of the Peelo Formation [Magri \& Bregman, 2011].

\section{Groundwater sampling}

We installed Poly-Vinyl-Chloride (PVC) piezometers using a hand auger. Each piezometer had a $20-\mathrm{cm}$ filter at the bottom. The piezometers were installed at each site at a depth of $1 \mathrm{~m}$ in the organic soil and underlying mineral soil, depending on the thickness of the peat. At the TaII site, we sampled water from a provincial well (reference number: B12D0281). This well had 8 piezometers at different depths up to $95 \mathrm{~m}$. We sampled water at 5 depths: F2, 9 m; F3, 17 m; F4, 40m; F5, $58 \mathrm{~m}$; F7, $82 \mathrm{~m}$; and F8, $95 \mathrm{~m}$. We also sampled the surface water in the streams at Kappersbult and Taarlo. All the pipes were flushed a day before sampling. The samples were collected at the end of October 2014, December 2014 and January 2015. The samples were stored in polyethylene bottles of 50 and $100 \mathrm{ml}$ for chemical analyses, and in $30 \mathrm{ml}$ bottles for oxygen and deuterium isotopes. The samples for radiocarbon dating were collected in $500 \mathrm{ml}$ dark glass bottles. All the samples were stored at the temperatures between 4 and $10^{\circ} \mathrm{C}$.

\section{Laboratory analyses}

\section{Isotopes}

\section{Radiocarbon dating}

Dissolved Inorganic Carbon (DIC) in the samples was extracted and trapped into $\mathrm{CO}_{2}$ gas, which was then converted into graphite. An Accelerator Mass Spectrometer (AMS) was used to count the carbon activity per second. The results are presented as ${ }^{14} \mathrm{C}$ percent modern carbon (pMC), which is the sample activity compared to a reference material with a known activity: ${ }^{14} \mathrm{C}_{\text {sample }}=\left({ }^{14} \mathrm{C}_{\text {measured }} /{ }^{14} \mathrm{C}_{\text {reference }}\right) \mathrm{pMC}[$ Mook, 2006].

\section{Stable isotopes $\left(\delta^{18} \underline{\mathrm{O} / \delta^{2}} \underline{H}\right)$}

The water samples were combusted and trapped into $\mathrm{CO}_{2}$ gas, which was then calibrated with the $\mathrm{CO}_{2}$ level of a reference material. The $\mathrm{CO}_{2}$ content was then measured using a Dual Inlet Isotope Ratio Mass Spectrometry "DI-IRMS" [Meijer, 2009], and standardized using the Vienna Standard Mean Ocean Water Reference "VSMOW", which has a set reference value of ocean water at $0 \%$ [Mook, 2006].

The quantification of the stable isotopic elements in a sample is based on comparing the measured sample to a standard with the following equation:

$$
\begin{aligned}
\delta_{\text {sample }}= & \left(R_{\text {measured }}-R_{\text {reference }}\right) \\
& / R_{\text {reference }}
\end{aligned}
$$

where $R_{\text {measured }}$ is the ratio of the measured heavy isotope content to the lighter one in a sample;

$\mathrm{R}$ reference represents the global reference sample, which is "VSMOW" in this case; and $\delta$ is the standardized measurement of the sample isotopic content.

\section{Ion composition}

The ion composition analyses were conducted at the Department of Experimental Plant Ecology at the University of Nijmegen in January 2015. The samples were filtered and analyzed. One subsample was used to measure the $\mathrm{pH}$ and total alkalinity by titration. Cations were measured by means of inductive coupled plasma spectrometry. Nutrients, as well as the chloride and sodium contents were analyzed using an auto-analyzer scalar (AAS). Total inorganic carbon (TIC) was measured with 1-ml fractions of the samples using an Infrared Gas Analyzer (ABB Advance Optima). The water samples with errors in the ionic balance of more than $10 \%$ were discarded.

\section{Data analyses}

\section{${ }^{14} \mathrm{C}$ correction and graphical representation}

Radiocarbon age is a function of the radiocarbon percentage in the samples, where the sample ages are inversely proportional to the radiocarbon percentage. The calculation of radiocarbon age is based on the following formula: sample age $=-8033 \ln \left({ }^{14} \mathrm{C}_{\text {measured }} / \mathrm{A}_{\mathrm{o}}\right)$, where $\mathrm{A}_{0}$ 
is the initial activity of radiocarbon at infiltration [Geyh, 2000; Mook, 2006]. We used two models for $A_{0}$ : (i) Tamer's alkalinity model to estimate $\mathrm{A}_{0}$ [Tamers, 1975] and (ii) the correction model by Vogel [1970] for the Netherlands, which assumes $\mathrm{A}_{0}=85 \mathrm{pMC}$. The samples with the values $>100 \mathrm{pMC}$ are assumed to have been influenced by the bomb effect, indicating recent infiltration (after 1950). The samples with values $<100 \mathrm{pMC}$ indicate possible infiltration before 1950 .

\section{Stable isotopes}

In order to present the stable isotope data, we plotted the values of the $\delta^{18} \mathrm{O}$ and $\delta^{2} \mathrm{H}$ against the Global and Local Meteoric Water Lines (GMWL and LMWL). The data for the GMWL and LMWL were obtained from the isotope observation network of the International Atomic Energy Agency (IAEA/WMO); the LMWL data were measured at the Groningen station in the network [IAEA/WMO, 2017]. The recent rainwater values for $\delta^{18} \mathrm{O}$ range around $-7.5 \pm 0.5 \%$ [IAEA/WMO, 2017]. These meteoric water lines were then used for the evidence of evaporation processes resulting from the exposure to the surface or high temperatures [Gat, 1996; Mook, 2006], which could indicate the DDC effect.

\section{Ion composition and Principal Component Analysis (PCA)}

In order to identify whether the water from various sources (different aquifers or DDC upwelling) exfiltrates into the fen peatlands at the Drentsche Aa, we used the multivariate statistical technique Principal Component Analysis (PCA). The Factoextra package in R was used to run PCA [Kassambara, 2017]. The data input consisted of the water concentrations of 15 ions and TDS (16 variables in total) measured in 32 water samples (26 plus the 6 repeated samples).

\section{RESULTS}

\section{Radiocarbon dating $\left({ }^{14} \mathrm{C}\right)$}

Table 1 shows the results from the radiocarbon dating and the corresponding calculated ages using both conventional calculation [Tamers, 1975] and the Vogel [1970] model. The samples that have the ${ }^{14} \mathrm{C}$ values higher than $85 \mathrm{pMC}$ and bomb ${ }^{14} \mathrm{C}$ values were interpreted as indicating the infiltration areas (Kappersbult, Deurze, Oudemolen and Loon). The relationships of the ${ }^{14} \mathrm{C}$ values with $\delta^{13} \mathrm{C}$ (Figure 3a) and the reciprocal of $\mathrm{HCO}_{3}$ (Figure $3 \mathrm{~b}$ ) can be classified into two groups for the groundwater with ${ }^{14} \mathrm{C}$ between 45 to $65 \mathrm{pMC}$. The first group includes the samples from Taarlo II and Rolderdiep I, which have the $\delta^{13} \mathrm{C}$ values between -14 to $-16 \%$ and and high $\mathrm{HCO}_{3}$ content $\left(1 / \mathrm{HCO}_{3}\right.$ lower than $\left.0.006 \mathrm{mg} / \mathrm{l}\right)$. Meanwhile, the other group includes the samples from Taarlo I and Rolderdiep II.

\section{Stable isotopes $\left({ }^{18} \mathrm{O}\right.$ and $\left.{ }^{2} \mathrm{H}\right)$}

Figure 4 shows the results of the $\delta^{18} \mathrm{O}$ and $\delta^{2} \mathrm{H}$ values with the GMWL and LMWL. We identified three groups (A, B and C) based on their $\delta^{18} \mathrm{O}$ values and their location with respect to the LMWL. Their $\delta^{18} \mathrm{O}$ values were -7.5 to $-7,-7$ to -6.5 and -6.5 to $-6 \%$ respectively. On the other hand, most of the samples in group A are above or right on the GMWL and the LMWL, the samples in groups $\mathrm{B}$ and $\mathrm{C}$ are mostly below the meteoric water lines, which indicates the possible effects of evaporation processes. Group A included the samples from Rolderdiep-II and Taarlo-I sites, while group B included the river water samples and some peat water samples from Rolderdiep-I and II, as well as Deurze. Lastly, group C included all the samples from Taarlo-II, and the samples from the mineral soil at Rolderdiep-I (RD-Ib) and Kappersbult (KB-d). The samples collected earlier in October showed only slightly different values from the ones sampled later in January.

\section{Ion composition}

The PCA resulted in 16 principal components (PC) with the first two explaining $56.23 \%$ of the data variation: $35.7 \%$ for $\mathrm{PC} 1$ and $20.5 \%$ for PC2, respectively. Figure 5 shows the ion variable loadings onto the principal components $\mathrm{PC} 1$ and PC2. The arrow lengths represent the magnitude of the variable loadings onto the PCA axes. Ion variables are grouped into clusters: cluster 1 contains most of the ions inversely proportional to $\mathrm{PC} 1$, cluster 2 contains the ions directly proportional to PC1 but inversely correlated to PC2 with the exception for $\mathrm{NH}_{4}$, and cluster 3 contains the ions directly proportional to both $\mathrm{PC} 1$ and $\mathrm{PC} 2$. For instance, the TDS and the bicarbonate and calcium ions are best represented by the first two components. In contrast, $\mathrm{NH}_{4}$ in cluster 2 is only 
Table 1. Age of groundwater calculated using (1) the alkalinity correction model [Tamers, 1975]

\begin{tabular}{|c|c|c|c|c|c|c|c|}
\hline \multirow[t]{2}{*}{$\#$} & \multirow[t]{2}{*}{ Code } & \multirow[t]{2}{*}{ Depth (m) } & \multirow{2}{*}{$\begin{array}{c}\mathrm{pH} \\
\text { (at } 20^{\circ} \mathrm{C} \text { ) }\end{array}$} & \multirow{2}{*}{$\begin{array}{c}{ }^{14} \mathrm{C} \\
(\mathrm{pMC})\end{array}$} & \multicolumn{2}{|c|}{ Tamers Model } & \multirow{2}{*}{\begin{tabular}{|c|}
$\begin{array}{c}\text { Vogel model } \\
\left(\mathrm{A}_{0}=85 \mathrm{pMC}\right)\end{array}$ \\
Age $(\mathrm{yrs})$
\end{tabular}} \\
\hline & & & & & $A_{0}(p M C)$ & Age (yrs) & \\
\hline 1 & Oudemolen & 0.2 & 4.76 & 109.3 & -- & -- & -- \\
\hline 2 & TA-SU & 0 & 7.59 & 71.01 & 55 & -- & 1490 \\
\hline 3 & TA-la & 0.9 & 7.08 & 73.19 & 58 & -- & 1240 \\
\hline 4 & TA-Ib & 3.5 & 7.38 & 45.26 & 55 & 1610 & 5210 \\
\hline 5 & TA-Ila & 1 & 7.30 & 47.32 & 55 & 1245 & 4845 \\
\hline 6 & TA-IIb & 3 & 7.42 & 65.39 & 55 & -- & 2170 \\
\hline 7 & TA-IIc F2 & 9 & 7.54 & 58.95 & 55 & -- & 3025 \\
\hline 8 & TA-IIc F3 & 15 & 7.58 & 102.2 & -- & -- & -- \\
\hline 9 & TA-IIc F4 & 25 & 7.50 & 49.08 & 55 & 940 & 4540 \\
\hline 10 & TA-IIc F5 & 38 & 7.57 & 45.33 & 55 & 1600 & 5110 \\
\hline 11 & TA-IIc F7 & 82 & 7.52 & 52.38 & 55 & 405 & 4005 \\
\hline 12 & TA-IIc F8 & 95 & 7.75 & 33.82 & 55 & 4020 & 7620 \\
\hline 13 & RD-la & 0.9 & 6.93 & 71.03 & 64 & 0 & 1485 \\
\hline 14 & RD-Ib & 5 & 6.84 & 55.78 & 64 & 1135 & 3485 \\
\hline 15 & RD-SU & 0 & 6.53 & 103.7 & -- & 0 & -- \\
\hline 16 & RD-Ila & 0.9 & 7.1 & 86.05 & 58 & 0 & -- \\
\hline 17 & RD-IIb & 3.5 & 6.74 & 46 & 68 & 3230 & 5080 \\
\hline 18 & L-a & 1 & 6.01 & 46.03 & 85 & 5070 & 5070 \\
\hline 19 & L-b & 4 & 6.99 & 91.8 & 58 & -- & -- \\
\hline 20 & De-b & 5.5 & 7.13 & 104.0 & 58 & -- & -- \\
\hline 21 & KB-SU & 0 & 7.75 & 73.9 & 52 & -- & 1160 \\
\hline 22 & KB-a & 1 & 6.69 & 104.2 & -- & -- & -- \\
\hline 23 & KB-C & 3 & 6.87 & 106 & -- & -- & -- \\
\hline 24 & KB-d & 6.3 & 7.16 & 108 & -- & -- & -- \\
\hline
\end{tabular}

Where: the $\mathrm{A}_{0}$ values ranged from 50 to $70 \mathrm{pMC}$, except for L-a, and (2) Vogel's model, which assumes $\mathrm{A}_{0}=$ 85 \pm 5 pMC [Vogel, 1970]. Site codes are: RD-I= Rolderdiep-I, RD-II = Rolderdiep-II, TA-I = Taarlo-I, TA-II = Taarlo-II, OM = Oudemolen, $\mathrm{L}=$ Loon, $\mathrm{De}=$ Deurze, $\mathrm{KB}=$ Kappersbult and $\mathrm{SU}=$ surface river water, while the peat samples codes are annexed with "a".

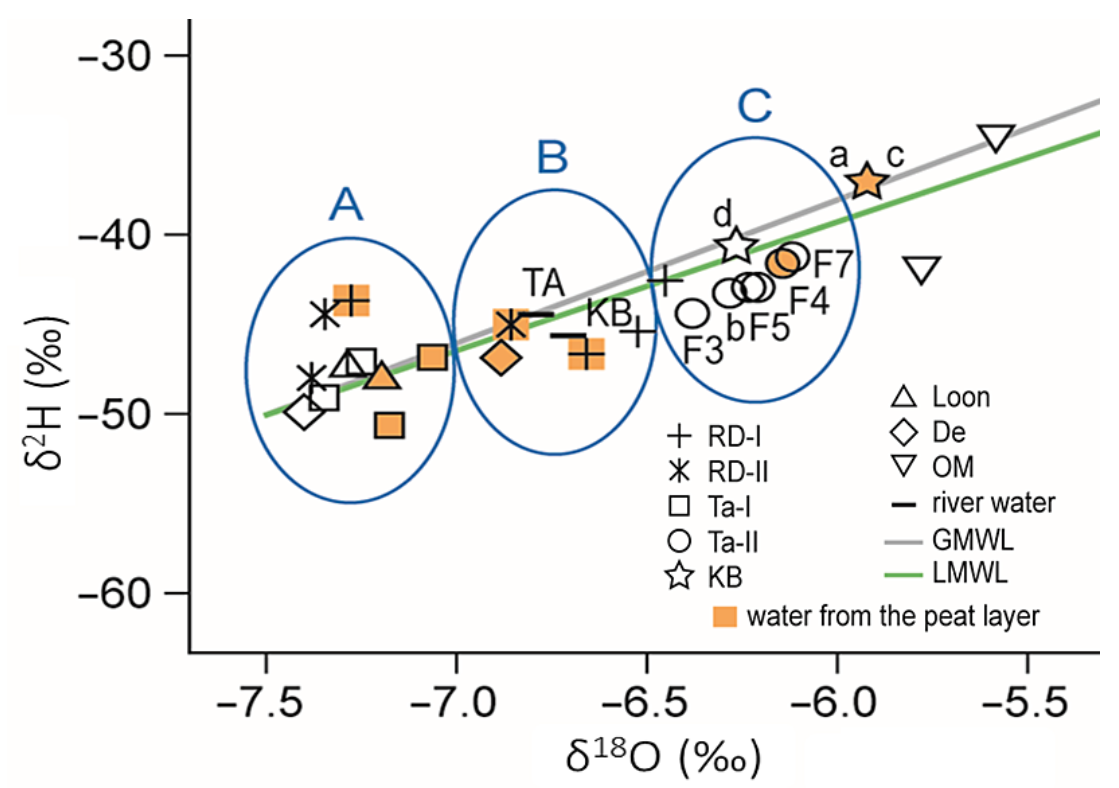

Figure 4. Stable isotopic compositions were plotted with GMWL and LMWL. The water samples collected from the peat layers are indicated with yellow filling 


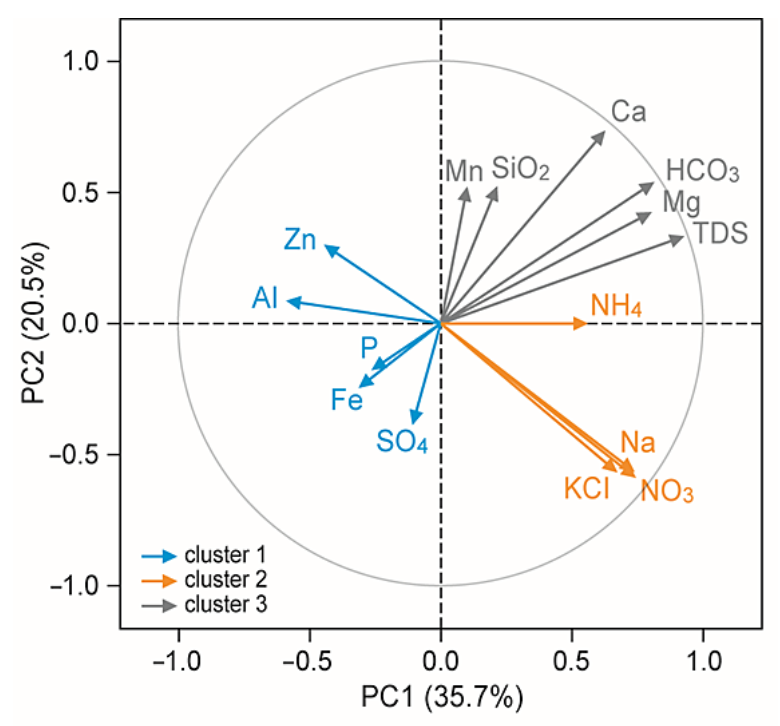

Figure 5. PCA plot of the macro-ionic content of the water samples. The arrow lengths indicate the variable loadings (ion composition) along the PCA axes, where the maximum of each loading is 1 . The clusters indicate the proportionality relation between the variables and the PCA axes

explained by $\mathrm{PC} 1$, as an increase of a sample $\mathrm{NH}_{4}$ content correlates with a positive position along $\mathrm{PC} 1$ and cannot be explained by changes in PC2.

Figure 6 shows the sample correlation to the first two PCs. Similarly, cos2 also indicates the quality of the sample representation and contribution to the PCs, e.g. the samples 16, 17, 19, 22 and 32 are best explained by the first two PCs, while the samples 5, 7, 11 and 31 are poorly explained.
There are distinct differences in ion composition among the bog samples taken from Oudemolen (23 and 24), the deep sample from Taarlo-II (TaIIc F8, 22) and the sample from the mineral soil at Kappersbult (KB-D, 32). The samples from Oudemolen are inversely proportional to both PC1 and PC2, which have low ion composition, except for $\mathrm{Fe}, \mathrm{P}$ and $\mathrm{SO}_{4}$. The deepest sample at Taarlo-II (Ta-IIF8), however, is directly proportional to $\mathrm{PC} 1$ with a distinctive increase in chloride, sodium and potassium. Kappersbult was directly proportional to both $\mathrm{PC} 1$ and $\mathrm{PC} 2$, with distinctive increases in calcium, bicarbonate, magnesium and overall TDS.

\section{DISCUSSION}

\section{Isotopes and origin of water flow}

\section{Sub-regional groundwater exfiltration sites}

We assumed that the samples with radiocarbon activities $>100$ pMC represent modern water. We observed that the shallow groundwater samples collected from the Taarlo (I and II) and Rolderdiep (I and II) sites indicate a possible exfiltration of water from the sub-regional aquifer. Using Han's graphical method, the sites with ${ }^{14} \mathrm{C}<60 \mathrm{pMC}$ could be separated into two groups: the first group contains Taarlo-II and Rolderdiep$\mathrm{I}$ and the second, Taarlo-I and Rolderdiep-II. These two groups in the ${ }^{14} \mathrm{C}$ data were based on the $\delta^{18} \mathrm{O} / \delta^{2} \mathrm{H}$ plot (groups $\mathrm{A}$ and $\mathrm{C}$ ) and to a lesser

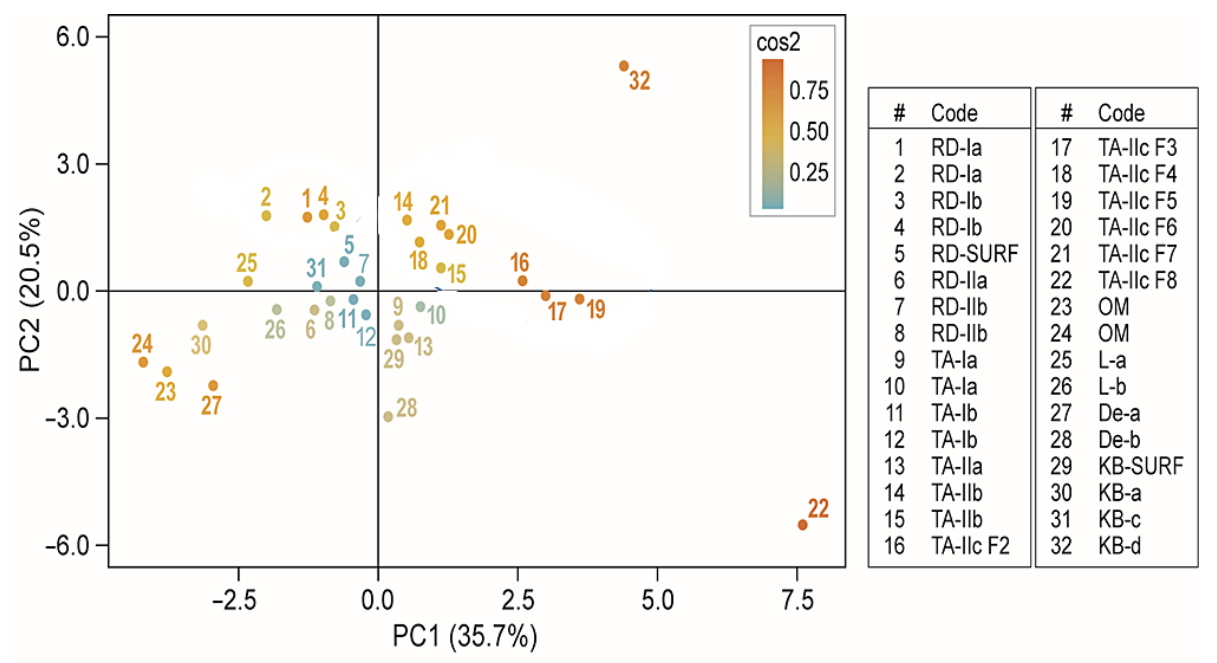

Figure 6. PCA plot of the sampling sites indicating correlations of the water samples to the first two PCA axes. The statistic $\cos 2$ indicates the quality of representation (contribution) of the samples by these two PCs. Site codes are: RD-I= Rolderdiep-I, RD-II = Rolderdiep-II, TA-I = Taarlo-I, TA-II = Taarlo-II, OM = Oudemolen, $\mathrm{L}=$ Loon, $\mathrm{De}=$ Deurze, $\mathrm{KB}=$ Kappersbult. 
degree, the PCA plots. These differences in stable isotopes could have resulted from the changes in the past climatic conditions during the time of recharge [Gat, 1996; Mook, 2006] or the surface conditions under which the infiltration took place, e.g. slow infiltration through peat layers [Mendizabal et al., 2011]. Therefore, it is more likely that the water flows exfiltrating into Taarlo-I and Rolderdiep-II are from similar sources but were influenced by different geochemical reactions from those at Taarlo-II and Rolderdiep-I. Taarlo-II and Rolderdiep-I could be also receiving water flows from the same sources.

\section{Infiltration and local groundwater exfiltration sites}

The groundwater samples under present-day infiltration regimes, post 1950, are identified by bomb ${ }^{14} \mathrm{C}(>100 \mathrm{pMC})$ as well as ${ }^{14} \mathrm{C}$ values higher than 85 pMC [Vogel, 1970]. Additionally, the $\delta^{2} \mathrm{H}$ and $\delta^{18} \mathrm{O}$ values for these samples are similar to the rainwater values at the recharge time $\left(\delta^{18} \mathrm{O}=-7.5 \pm 0.5 \%\right.$ for The Netherlands), which indicates the dominance of modern water [Clark \& Aravena, 2005; Mook, 2006]. Such values were observed in four sites in this study: Oudemolen,

Appendix 1. Full results of the Ion composition analyses of the water samples. TDS = total dissolved salts

\begin{tabular}{|c|c|c|c|c|c|c|c|c|c|c|c|c|c|c|c|c|c|c|c|c|}
\hline \# & Date & Code & $\begin{array}{c}\text { Depth } \\
(\mathrm{m})\end{array}$ & $\begin{array}{c}\mathrm{pH} \\
\left(20^{\circ} \mathrm{C}\right)\end{array}$ & \begin{tabular}{|c|} 
TDS \\
$(\mathrm{mg} / \mathrm{l})$
\end{tabular} & $\begin{array}{l}\mathrm{HCO}_{3} \\
(\mathrm{mg} / \mathrm{l})\end{array}$ & \begin{tabular}{|c|}
$\mathrm{SO}_{4}$ \\
$(\mathrm{mg} / \mathrm{l})$
\end{tabular} & $\begin{array}{c}\mathrm{Cl} \\
(\mathrm{mg} / \mathrm{l})\end{array}$ & $\begin{array}{c}\mathrm{NO}_{3} \\
(\mathrm{mg} / \mathrm{l})\end{array}$ & $\begin{array}{c}\mathrm{Ca} \\
(\mathrm{mg} / \mathrm{l})\end{array}$ & $\begin{array}{c}\mathrm{Na} \\
(\mathrm{mg} / \mathrm{l})\end{array}$ & $\begin{array}{c}\mathrm{P} \\
(\mathrm{mg} / \mathrm{l})\end{array}$ & $\begin{array}{c}\mathrm{K} \\
(\mathrm{mg} / \mathrm{l})\end{array}$ & $\begin{array}{c}\mathrm{Mg} \\
(\mathrm{mg} / \mathrm{l})\end{array}$ & $\begin{array}{c}\mathrm{Mn} \\
(\mathrm{mg} / \mathrm{l})\end{array}$ & $\begin{array}{c}\mathrm{Fe} \\
(\mathrm{mg} / \mathrm{l})\end{array}$ & $\begin{array}{c}\mathrm{Al} \\
(\mathrm{mg} / \mathrm{l})\end{array}$ & $\begin{array}{c}\mathrm{Si} \\
(\mathrm{mg} / \mathrm{l})\end{array}$ & $\begin{array}{c}\mathrm{NH}_{4} \\
(\mathrm{mg} / \mathrm{l})\end{array}$ & $\begin{array}{c}\mathrm{Zn} \\
(\mathrm{mg} / \mathrm{l})\end{array}$ \\
\hline 1 & $10-30-14$ & RD la & 1 & 6.93 & 279 & 180.5 & 0.7 & 10 & 0.6 & 61 & 7.5 & 0.02 & 0.3 & 4.6 & 0.25 & 0.40 & 0.25 & 12.01 & 0.005 & 0.26 \\
\hline 2 & $12-5-14$ & RD la & 1 & 6.84 & 265 & 167.7 & 1.2 & 12 & 0.7 & 57 & 8.4 & 0.05 & 0.3 & 4.5 & 0.25 & 0.43 & 0.35 & 12.00 & 0.01 & 0.44 \\
\hline 3 & $10-30-14$ & $\mathrm{Rd} \mathrm{lb}$ & 5 & 7.30 & 295 & 196.1 & 0.6 & 12 & 0.8 & 56 & 9.9 & 0.03 & 1.2 & 5.7 & 0.33 & 0.04 & 0.35 & 12.05 & 0.02 & 0.22 \\
\hline 4 & $12-5-14$ & $\mathrm{RD} \mathrm{lb}$ & 5 & 7.16 & 290 & 206.4 & 0.3 & 5 & 0.3 & 54 & 4.9 & 0.03 & 0.7 & 5.6 & 0.33 & 0.02 & 0.30 & 11.88 & 0.02 & 0.12 \\
\hline 5 & $12-5-14$ & RD SURF & 0 & 6.53 & 230 & 142.1 & 0.9 & 20 & 1.2 & 42 & 11.0 & 0.03 & 1.6 & 4.8 & 1.11 & 0.05 & 0.20 & 5.48 & 0.13 & 0.15 \\
\hline 6 & $12-9-14$ & RD Ila & 1 & 7.10 & 222 & 118.8 & 19.3 & 16 & 1.0 & 41 & 9.0 & 0.03 & 1.2 & 4.2 & 0.00 & 0.06 & 0.18 & 11.11 & 0.02 & 0.10 \\
\hline 7 & $10-30-14$ & RD Ilb & 3.5 & 6.74 & 242 & 152.2 & 0.9 & 17 & 1.0 & 45 & 10.1 & 0.03 & 2.6 & 4.7 & 0.69 & 0.56 & 0.15 & 7.95 & 0.01 & 0.12 \\
\hline 8 & $12-5-14$ & $\mathrm{RD} \| \mathrm{b}$ & 3.5 & 7.22 & 238 & 135.1 & 18.2 & 16 & 1.0 & 43 & 8.8 & 0.02 & 1.1 & 4.3 & 0.07 & 0.07 & 0.12 & 10.82 & 0.03 & 0.10 \\
\hline 9 & $12-5-14$ & TA SURF & 0 & 7.59 & 308 & 180.7 & 14.6 & 28 & 1.7 & 50 & 15.3 & 0.04 & 2.2 & 5.1 & 0.00 & 0.16 & 0.12 & 8.97 & 0.03 & 0.10 \\
\hline 10 & $10-30-14$ & TA la & 1 & 7.08 & 312 & 187.1 & 10.6 & 20 & 1.2 & 60 & 14.1 & 0.03 & 3.2 & 4.4 & 0.02 & 0.02 & 0.08 & 11.42 & 0.28 & 0.13 \\
\hline 11 & $12-5-14$ & TA la & 1 & 7.24 & 290 & 191.0 & 4.8 & 14 & 0.9 & 52 & 10.5 & 0.10 & 1.8 & 4.1 & 0.01 & 0.80 & 0.08 & 10.33 & 0.03 & 0.09 \\
\hline 12 & $10-30-14$ & TA Ib & 3.5 & 7.37 & 260 & 143.7 & 18.7 & 19 & 1.2 & 48 & 12.3 & 0.02 & 2.4 & 4.1 & 0.12 & 0.07 & 0.07 & 10.13 & 0.05 & 0.17 \\
\hline 13 & $12-5-14$ & TA lb & 3.5 & 7.36 & 291 & 164.0 & 16.3 & 25 & 1.5 & 50 & 18.1 & 0.02 & 2.7 & 4.1 & 0.00 & 0.02 & 0.05 & 10.02 & 0.08 & 0.07 \\
\hline 14 & $12-5-14$ & TA lla & 1 & 7.32 & 375 & 268.1 & 0.5 & 10 & 0.6 & 69 & 9.8 & 0.03 & 0.7 & 7.5 & 0.15 & 0.06 & 0.09 & 8.27 & 0.03 & 0.13 \\
\hline 15 & $12-5-14$ & TA Ilb & 3 & 7.42 & 362 & 243.4 & 0.3 & 20 & 1.3 & 59 & 19.2 & 0.02 & 2.0 & 6.5 & 0.08 & 0.01 & 0.05 & 9.59 & 0.03 & 0.15 \\
\hline 16 & $12-9-14$ & TA Ilc F2 & 9 & 7.54 & 408 & 253.1 & 2.8 & 39 & 2.4 & 73 & 17.7 & 0.02 & 2.1 & 7.5 & 0.13 & 0.02 & 0.04 & 9.86 & 0.26 & 0.06 \\
\hline 17 & $12-9-14$ & TA llc F3 & 17 & 7.58 & 434 & 263.0 & 3.4 & 47 & 2.9 & 72 & 26.2 & 0.02 & 2.0 & 7.1 & 0.14 & 0.01 & 0.03 & 10.10 & 0.24 & 0.06 \\
\hline 18 & $12-9-14$ & TA Ilc F4 & 26 & 7.50 & 351 & 247.9 & 0.3 & 12 & 0.7 & 60 & 12.9 & 0.02 & 1.3 & 6.0 & 0.21 & 0.04 & 0.06 & 9.60 & 0.25 & 0.10 \\
\hline 19 & $12-9-14$ & TA llc F5 & 40 & 7.57 & 547 & 376.3 & 0.2 & 49 & 3.0 & 60 & 41.0 & 0.02 & 1.9 & 5.8 & 0.12 & 0.02 & 0.04 & 9.56 & 0.27 & 0.07 \\
\hline 20 & $12-9-14$ & Ta Ilc F6 & 58 & 7.44 & 389 & 273.3 & 0.1 & 15 & 0.9 & 70 & 12.6 & 0.01 & 1.2 & 6.3 & 0.18 & 0.06 & 0.03 & 9.56 & 0.22 & 0.08 \\
\hline 21 & $12-9-14$ & TA Ilc F7 & 82 & 7.52 & 384 & 271.2 & 0.2 & 13 & 0.8 & 72 & 9.5 & 0.01 & 1.1 & 6.6 & 0.13 & 0.03 & 0.05 & 10.01 & 0.21 & 0.08 \\
\hline 22 & $12-9-14$ & TA Ilc F8 & 95 & 7.75 & 545 & 262.3 & 0.2 & 115 & 7.1 & 35 & 105.9 & 0.04 & 5.4 & 6.7 & 0.04 & 0.05 & 0.04 & 7.47 & 0.94 & 0.07 \\
\hline 23 & $10-29-14$ & OM & 0.2 & 4.73 & 19 & 0.4 & 2.6 & 5 & 0.3 & 1 & 5.9 & 0.06 & 0.6 & 0.7 & 0.02 & 0.34 & 0.23 & 1.47 & 0.71 & 0.24 \\
\hline 24 & $12-9-14$ & OM & 0.2 & 4.76 & 22 & 0.4 & 2.0 & 7 & 0.5 & 1 & 6.6 & 0.03 & 0.6 & 0.6 & 0.03 & 0.26 & 0.18 & 1.42 & 0.16 & 0.37 \\
\hline 25 & $12-7-14$ & L-a & 1 & 6.91 & 166 & 99.3 & 8.4 & 5 & 0.3 & 29 & 5.4 & 0.05 & 0.4 & 2.1 & 0.00 & 0.49 & 0.10 & 15.38 & 0.06 & 0.18 \\
\hline 26 & $12-7-14$ & $L-b$ & 4 & 7.13 & 165 & 76.4 & 21.3 & 10 & 0.6 & 27 & 10.8 & 0.02 & 0.8 & 2.0 & 0.00 & 0.26 & 0.07 & 16.38 & 0.05 & 0.12 \\
\hline 27 & $12-5-14$ & De-a & 1 & 6.01 & 95 & 11.7 & 2.7 & 37 & 2.3 & 8 & 17.8 & 0.04 & 0.8 & 1.2 & 0.03 & 3.40 & 0.40 & 9.50 & 0.06 & 0.22 \\
\hline 28 & $12-7-14$ & De-b & 5.5 & 6.99 & 257 & 79.0 & 50.6 & 40 & 2.5 & 39 & 21.2 & 0.07 & 2.6 & 6.8 & 0.01 & 5.97 & 0.03 & 8.31 & 0.07 & 0.14 \\
\hline 29 & $12-5-14$ & KB SURF & 0 & 7.75 & 267 & 147.7 & 15.4 & 28 & 1.7 & 44 & 15.4 & 0.01 & 2.2 & 4.9 & 0.00 & 0.22 & 0.04 & 8.16 & 0.04 & 0.09 \\
\hline 30 & $12-5-14$ & KB-a & 1 & 6.69 & 155 & 81.5 & 3.2 & 10 & 0.6 & 32 & 5.0 & 0.05 & 0.3 & 2.2 & 0.10 & 10.96 & 0.12 & 8.24 & 0.06 & 0.23 \\
\hline 31 & $12-5-14$ & KB-C & 3 & 6.87 & 288 & 176.8 & 2.5 & 22 & 1.4 & 54 & 11.0 & 0.17 & 0.4 & 4.7 & 0.40 & 5.39 & 0.09 & 9.15 & 0.16 & 0.20 \\
\hline 32 & $12-8-14$ & KB-d & 6.3 & 7.16 & 643 & 445.8 & 1.8 & 21 & 1.3 & 131 & 13.4 & 0.02 & 0.7 & 9.5 & 0.70 & 0.14 & 0.03 & 17.30 & 1.17 & 0.37 \\
\hline
\end{tabular}



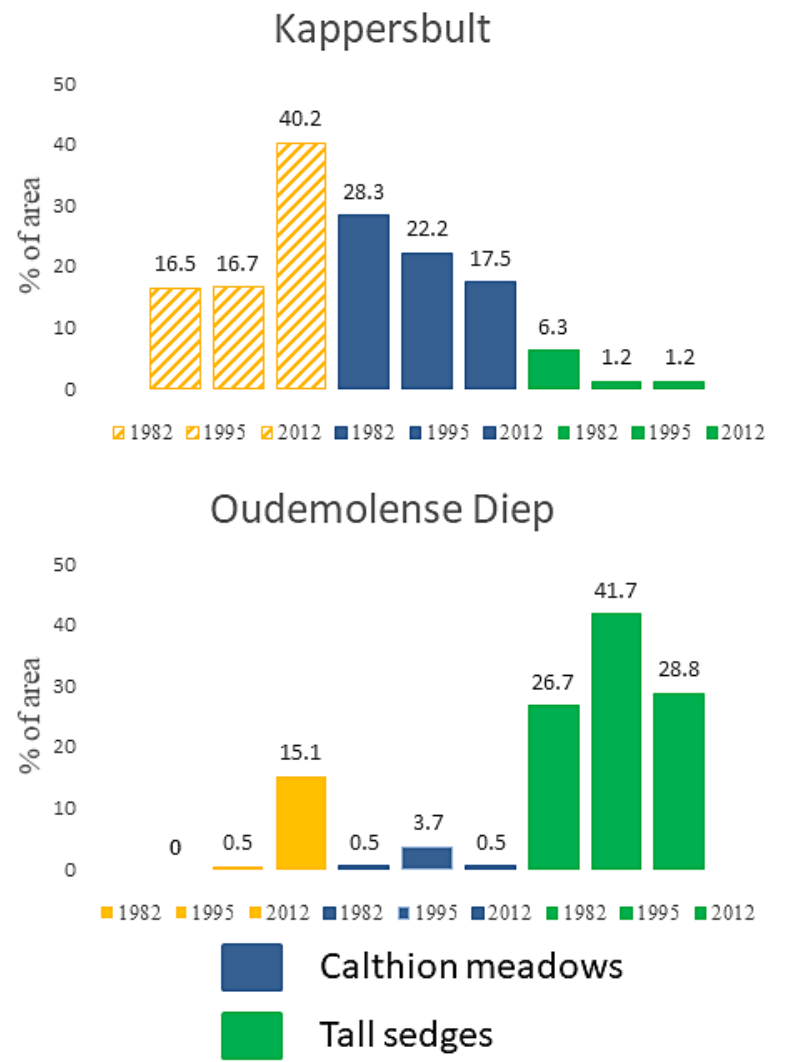
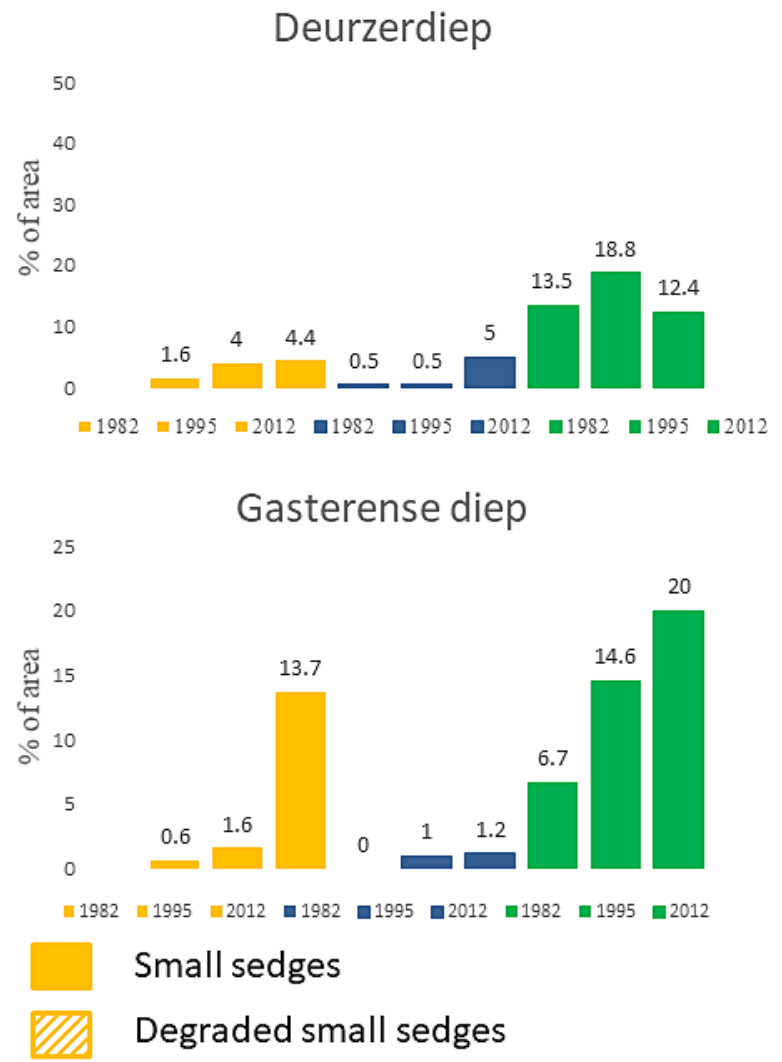

Appendix 2. Vegetation mapping data from 1982-2012 to assess the success of restoration activities (Adapted from Bakker et al. 2015). The vegetation type density per area is shown at four sites: Kappersbult, Gasterense

Diep and Oudemolense Diep (Taarlo and Rolderdiep sites) and Deurzer Diep (Deurze).

Deurze, Loon and Kappersbult. The first two are hypothesized already to reflect the infiltration and local system supply regimes; however, earlier studies indicated that Loon and Kappersbult should be supplied by sub-regional groundwater flows [Everts \& De Vries, 1991; Magri \& Bregman, 2011]. Thus, the latter sites likely indicate groundwater abstraction influence on the natural groundwater flow systems.

Oudemolen reflects the sole dependency on rainwater supply. The chemical analysis of the water samples from the small bog at Oudemolen confirmed that this water is acidic $(\mathrm{pH}=4.7)$ and poor in minerals. The low $\mathrm{Cl}^{-}$content $(\sim 5-7 \mathrm{mg} / \mathrm{l})$ also indicates rain water infiltration [Appelo \& Postma, 2005]. However, the stable isotope values indicate enrichment of $\delta^{18} \mathrm{O}$ and $\delta^{13} \mathrm{C}$ isotopes ( 5.8 and $10.2 \%$ respectively), which is due to evaporation as the precipitation is hampered by the impervious organic layer [Schot \& Wassen, 1993]. This site reflects a natural infiltration zone, which is isolated from the surrounding due to the podzol zone formation. Here, it reflects the water quality of rainwater/infiltration patterns. This pattern is then different for the other site, i.e.
Deurze, Loon and Kappersbult, which reflect an anthropogenic influence.

The Deurze-b site in the upper reaches of the valley, which is also underlain by thick impervious Elsterian clay layers at shallow depths, is identified as being supplied by the phreatic groundwater flows from a local hydrological system [Magri \& Bregman, 2011]. The isotopic evidence indicate that the site is supplied by infiltration and local groundwater flow. For instance, the samples show bomb ${ }^{14} \mathrm{C}$ values (>100 pMC) as well as the $\delta^{13} \mathrm{C}$ content, which shows a shift towards enrichment by organic material $(-20 \%)$. However, the groundwater has a higher mineral content, especially in $\mathrm{Na}^{+}$and $\mathrm{Cl}^{-}$. The nutrient content of this site is higher than in the rest of the study sites $\left(\mathrm{NO}_{3}^{-}>2.5 \mathrm{mg} / \mathrm{l}\right)$, which indicates possible pollution due to the agricultural activities [Schot \& Van der Wal, 1992].

As for Kappersbult and Loon, ${ }^{14} \mathrm{C}$ the data also indicate that they are infiltration sites or locally supplied. Both these sites are situated close to the groundwater abstraction facilities in Glimmen and Assen, respectively. The hydrogeologic setting of these sites would suggest 
possible exfiltration of the sub-regional groundwater flows similarly to the Taarlo and Rolderdiep sites. Yet, the radiocarbon data in Kappersbult showed the values of bomb ${ }^{14} \mathrm{C}$, indicating infiltration of water on the surface. The macro-ion composition showed the values of high $\mathrm{Ca}$ and $\mathrm{HCO}_{3}$ compared with the other infiltration areas. This most likely resulted from the dissolution of the minerals from the deeper peat layers, due to infiltration of $\mathrm{CO}_{2}$-rich groundwater from upper layers [Schot \& Wassen, 1993; Brandyk et al., 2007]. The released $\mathrm{CO}_{2}$ enhances the dissolution of soil minerals, in our case $\mathrm{Ca}$ and $\mathrm{HCO}_{3}$ [Appelo \& Postma, 2005]. Therefore, we can conclude that the flow regime has been changed, most likely by the activities of the groundwater abstraction facility near Glimmen [Van Diggelen et al., 1993].

The samples at Loon (both at depths of 1 and $4 \mathrm{~m}$ ) had low concentrations of macro-ions. This was unexpected, since thick peat layers are present here at the depth of $3 \mathrm{~m}$, and indicates strong seepage conditions in the past. The ${ }^{14} \mathrm{C}$ analysis of Loon showed a modern water signature of 91 $\mathrm{pMC}$. Therefore, we argue that a change in the water regime had also occurred at this site, in which an exfiltration area was shifted towards infiltration. The Loon site now likely receives the groundwater from a nearby extensive heathland infiltration area, Balloerveld. The existing groundwater abstraction facility near the city of Assen has apparently reduced the discharge of groundwater from the second aquifer and consequently increased the inflow of groundwater from more local groundwater systems. It confirms the effect of groundwater abstraction on natural groundwater flows, which was indicated by Magri \& Bregman [2011]. In their study, different scenarios were computed, which indicated that even lowering the groundwater abstraction from $6 \mathrm{~mm}^{3}$ to $3 \mathrm{~mm}^{3}$ did not stop the negative impact on the groundwater system.

\section{Relic situations}

There was one unexpected outcome of the ${ }^{14} \mathrm{C}$ measurements. On two occasions while sampling at Loon and Taarlo-II, we found older groundwater in the upper peat layer (at the depth of $1 \mathrm{~m}$ below the surface) compared with the groundwater in the underlying mineral sand deposits. We have interpreted this as the presence of older relic groundwater in the peat layer. Under the conditions of changed groundwater flows, sand deposits can react faster to the hydrological changes compared with thick organic peat layers.

\section{Evidence of double diffusive convection (DDC)}

The radiocarbon data indicate that the sample from the provincial well (B12D0281 at TaarloII) at a depth of $95 \mathrm{~m}$ has the lowest ${ }^{14} \mathrm{C}$ content, about $33 \mathrm{pMC}$. This makes the sample clearly distinct from the groups related to the samples indicating sub-regional groundwater flows. Furthermore, it deviates from the rest of the samples in the PCA plot (sample nr. 22; Figure 6), due to a water type change from $\mathrm{CaHCO}_{3}$ to $\mathrm{NaHCO}_{3}$. This sample, and some other ones all south of the slip-fault (Figure 2a) that were also sampled and reported in 1995 by the province of Drenthe [1995], are the only ones indicating the upwelling of the deep groundwater. It is likely to originate from below the, currently considered, hydrological basis of the regional groundwater, Breda Formation. Despite this, the DDC effect on the fen water quality cannot be confirmed at our sites, as the deep groundwater flows were not shown to mix with exfiltrating sub-regional/shallow flows near the surface. It would still be wise to take more measurements from other deep wells in the valley to check whether salt plumes could exist at the depths shallow enough to affect the vegetation communities at the surface.

\section{CONCLUSIONS}

The study area is part of the Ice Marginal Landscape with salt formations in the deeper subsurface. Due to the glaciological processes and geo-hydrological conditions, we expect that the results of our study are important not only for the Drentsche Aa area, but also for other countries and regions in the IML zone from the Netherlands to Lithuania. We think that the results of our study contribute to a better understanding of groundwater flows as a base for nature conservation and other functions of the landscape.

The data indicated that the groundwater abstraction activities affecting these sites appear to have also affected the restoration success in various sections of the study area. The analysis of 30 years, in 10-year lapses, of vegetation data from 1992 to 2012 indicated good recovery after restoration management in the areas not affected by the abstraction of groundwater, e.g. Taarlo and Rolderdiep (Appendix 2) [Bakker et al., 2015]. In contrast, the areas that were affected did not show similar increases in target species, 
e.g. Kappersbult. Unlike other sites, Kappersbult showed poor results in the restoration of the hydrological conditions and its target species. Although the groundwater abstraction has been reduced, the groundwater flow simulations of lowered abstraction scenarios indicate that the impact still will have a negative influence on the wetland vegetation in future [Magri \& Bregman, 2011]. However, it could be that the impact of the taken measures would simply take more time to recover. Despite the measures to reduce drainage in the area south of the fault zone, between Loon Oudemolen and Rolderdiep, which leads to drainage and floating of peat, the groundwater system seems to be still in unbalance. However, recovery of the groundwater system seems to be successful.

It is necessary to follow up on the inter-relationship of the deep saline groundwater flows to the relatively shallow fresh groundwater systems. Hence, further monitoring of the groundwater quality in combination with study of the vegetation development is advised.

\section{Acknowledgements}

We would like to acknowledge StaatsBosBeheer (Dutch State Forestry) for allowing us to sample groundwater, the Province of Drenthe for sampling the deep wells, Christian Fritz for analyzing the macro-ion data at Radboud University, Harro Meijer and Hans van der Plicht for allowing the isotope analysis to be conducted at CIO, Groningen, and Rien Herber for his help with this project.

\section{REFERENCES}

1. Appelo C.A.J., Postma D. 2005. Geochemistry, Groundwater and Pollution (2nd ed.). Amsterdam.

2. Bakker J.P., Dekker M., \& De Vries Y. 1980. The effect of different management practices on a grassland community and the resulting fate of seedlings. Acta Botanica Neerlandica 29, 469-482.

3. Bakker J.P., Everts H., Grootjans A.P., De Vries N.P.J., De Vries Y. 2015. The big experiment - Fifty years of Nature Management. In: Spek, T., Elerie H., Bakker, J.P., Noordhoff, I. (eds.), Landscape biogeography of the Drentsche Aa (pp. 418-461). Koninklijke Van Gorcum BV, Assen. (In Dutch)

4. Bregman E.P.H., Maas G., Makaske B., \& Meyles E, 2015. Formed by Ice, Water and Wind In: Spek T, Elerie H, Bakker JP, Noordhoff I (eds):
Landscape biogeaography of the Drentsche Aa, pp. 18-53. Van Gorcum, Assen. (In Dutch)

5. Clark I., \& Aravena R. 2005. Environmental Isotopes in Ground Water Resource and Contaminant Hydrogeology. National Ground Water Agency, US.

6. Dahl M., Nilsson B., Langhoff J.H., Refsgaard J.C. 2007. Review of classification systems and new multi-scale typology of groundwater-surface water interaction. Journal of Hydrology 344, 1-16.

7. De Gans W. 2007. Quaternary. In: Wong TE, Batjes DAJ, De Jager J (eds.), Geology of the Netherlands (pp. 173-195). Royal Netherlands Academy of Arts and Sciences, Amsterdam.

8. Diersch H., \& Kolditz O. 1998. Coupled groundwater flow and transport: 2 . Thermohaline and 3D convection systems. Advances in Water Resources 1708, 401-425.

9. DINOLOKET (2014). Retrieved October 15, 2014, from https://www.dinoloket.nl/

10. Everts F.H. \& de Vries N.P.J. 1991. De vegetatieontwikkeling van beekdalsystemen. Proefschrift Rijksuniversiteit Groningen/ Historische uitgeverij Groningen.

11. Gat J.R. 1996. Oxygen and hydrogen isotopes in the hydrologic cycle. Earth and Planetary Science 24, 225-262.

12. Geyh M. 2000. An overview of $14 \mathrm{C}$ analysis in the study of groundwater. Radiocarbon 42, 99-114.

13. Gibson J. J., Edwards T.W.D., Birks S.J., St Amour N.A., Buhay W.M., McEachern P., \& Peters D.L. 2005. Progress in isotope tracer hydrology in Canada. Hydrological Processes, 19(1), 303-327.

14. Gilvear D.J., \& Bradley C. 2009. Hydrological Dynamics II: Groundwater and Hydrological Connectivity. In: Maltby, E. \& Barker, T. (eds.): The Wetlands Handbook (pp. 169-193). Wiley-Blackwell Publishing, Chichester.

15. Grootjans A.P., Van Diggelen R., Everts F.H., Schipper P.C., Streefkerk, J., De Vries N.P.J., \& Wierda A. 1993. Linking ecological patterns to hydrological conditions on various spatial scales: a case study of small stream valleys. In: Vos, C.C., \& Opdam, P. (eds.): Landscape Ecology of a Stressed Environment (pp. 60-78). Chapman and Hall, London.

16. IAEA/WMO 2017. Global Network of Isotopes in Precipitation. The GNIP Database. Accessible at: http://www.iaea.org/water

17. Isokangas E., Rossi, P.M., Ronkanen A.-K., Marttila H., Rozanski K. \& Kløve B. 2017. Quantifying spatial groundwater dependence in peatlands through a distributed isotope mass balance approach. Water Resour. Res., 53, 2524-2541.

18. Kassambara A. 2017. Practical Guide to Principal Component Methods in R. Accessible at: www.Sthda.com. 
19. Magri F., \& Bregman E.P.H. 2011. Regional-scale numerical model of coupled fluid flow and mass transport along a deep geological profile in the Drenthe area, The Netherlands. Final Report of the Demo Pilot Project. Geowissenschaften Institut für Geologische Wissenschaften, Berlin.

20. Mayer A., Sültenfuß J., Travi Y., Rebeix R., Purtschert R., Claude C., \& Conchetto E. 2014. A multi-tracer study of groundwater origin and transit-time in the aquifers of the Venice region (Italy). Applied Geochemistry 50, 177-198. http://doi. org/10.1016/j.apgeochem.2013.10.009

21. Meijer H.A.J. 2009. Stable isotope quality assurance using the "calibrated IRMS" strategy. Isotopes in Environmental and Health Studies 45, 150-163.

22. Mendizabal I., \& Stuyfzand P. 2009. Guidelines for interpreting hydrochemical patterns in data from public supply well fields and their value for natural background groundwater quality determination. Journal of Hydrology 379(1-2), 151-163.

23. Mendizabal I., Stuyfzand P. \& Wiersma A. 2011. Hydrochemical system analysis of public supply well fields, to reveal water-quality patterns and define groundwater bodies: The Netherlands. Hydrogeology Journal 19, 83-100.

24. Mook W.G. 2006. Introduction to Isotope Hydrology. International Association of Hydrogeologists, Vienna.

25. Province of Drenthe 1995. Research on the dynamic behaviour of groundwater systems. Report (in Dutch). Province of Drenthe, Assen.

26. Schot P.P., \& Van der Wal J. 1992. Human impact on regional groundwater composition through intervention in natural flow patterns and changes in land use. Journal of Hydrology 134, 297-313.

27. Schot P.P., \& Wassen M.J. 1993. Calcium concentrations in wetland groundwater in relation to water sources and soil conditions in the recharge area. Journal of Hydrology 141, 197-217.

28. Smit F.W.H., Magri F., Bregman E.P.H. 2018. Coupling earth surface processes and geological struc- tures to explain environmental features as observed onshore Northern Netherlands. SEG conference 2018 paper (accepted).

29. Tamers M.A. 1975. The validity of radiocarbon dates on groundwater. Geophysical Survey 2, 217-239.

30. Tóth J. 1963. A theoretical analysis of groundwater flow in small drainage basins. Journal of Geophysical Research 68, 4795-4812.

31. Van Diggelen R., Grootjans, A.P., \& Burkunk, R. 1994. Assessing restoration perspectives of disturbed brook valleys: the Gorecht area, The Netherlands. Restoration Ecology 2, 87-96.

32. Van Diggelen R., Beukema H., \& Noorman K.J. 1995. Ranunculus hederaceus L. as indicator of land use changes in the Netherlands. Acta Botanica Neerlandica 44, 161-175.

33. Van Loon A.H., Schot P.P., Griffioen J., Bierkens M.F.P., Batelaan O., Wassen M.J. 2009. Throughflow as a determining factor for habitat contiguity in a near-natural fen. Journal of Hydrology 379, 30-40.

34. Vogel J.C. 1970. Carbon-14 dating of groundwater. In: Isotope Hydrology, Proceedings of a symposium. (pp. 225-236). Vienna: International Atomic Energy Association.

35. De Vries J.J. (2007). Groundwater. In: Wong, T.E., Batjes, D.A.J. \& De Jager, J. (eds.), Geology of The Netherlands. Royal Netherlands Academy of Arts and Sciences (pp. 295-315), Amsterdam.

36. Wassen M.J., Barendregt A., Palczynski A., De Smidt J.T., \& De Mars H. 1990. The relationship between fen vegetation gradients; groundwater flow and flooding in an undrained valley mire at Biebrza, Poland. Journal of Ecology 78, 1106-1122.

37. Wheeler B.D., \& Shaw S.C. 1995. Plants as Hydrologists? An assessment of the value of plants as indicators of water conditions in fens. In: Hughes M.R., Heathwaite A.L. (eds.), Hydrology and Hydrochemistry of British Wetlands (pp. 63-82). West Sussex: John Wiley. 